\title{
Analytic network process (ANP) approach for product mix planning in railway industry
}

\author{
Hadi Pazoki Toroudi ${ }^{a}$, Mahsa Sadat Madani ${ }^{\mathrm{b}}$ and Fatemeh Sarlak
}

${ }^{a}$ Department of Industrial Engineering, Ghaemshahr Branch, Islamic Azad University, Ghaemshahr, Iran

${ }^{b}$ Department of Industrial Engineering, TaJan University, Ghaemshahr, Iran

${ }^{c}$ Department of Industrial Engineering, College of Engineering, University of Tehran, Tehran, Iran

\section{H R O N I C L E}

Article history:

Received January 5, 2016

Received in revised format June

15,2016

Accepted July 14, 2016

Available online

July 14, 2016

Keywords:

Product selection

ANP

Analytical Network Process

\section{A B S T R A C T}

\begin{abstract}
Given the competitive environment in the global market in recent years, organizations need to plan for increased profitability and optimize their performance. Planning for an appropriate product mix plays essential role for the success of most production units. This paper applies analytical network process (ANP) approach for product mix planning for a part supplier in Iran. The proposed method uses four criteria including cost of production, sales figures, supply of raw materials and quality of products. In addition, the study proposes different set of products as alternatives for production planning. The preliminary results have indicated that the proposed study of this paper could increase productivity, significantly.
\end{abstract}

\section{Introduction}

During the past years, there have been tremendous efforts on using multi criteria decision making techniques for production planning (Abedini et al., 2013; Paul et al., 2015). There is no doubt that profit maximization is not the only criterion for making strategic decision in today's marketing planning and other criteria including quality, political affairs, environmental issues, etc. influence planning decisions. Zarepour and Momeni (2014) performed an investigation to investigate various factors influencing on auto parts in Iran. The study requested some experts who worked for an auto parts supplier named SaipaYadak to express their opinions about the relative importance of factors affecting demand for auto parts in various regions of the Iran and their opinions were grouped into four groups of parts related issues, weather conditions, regional as well as cultural factors. They also used analytical network process (ANP) (Saaty, 1996) to rank various factors and their results indicated that regional factors were the most important items followed by cultural issues, auto parts and weather conditions. Kuan and Chen (2014) proposed a hybrid MCDM framework combined with DEMATEL-based ANP to make an assessment on enterprise technological innovation capabilities assessment.

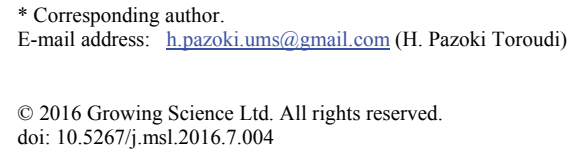


Atafar et al. (2013) presented a hybrid of balance score card (Kaplan, \& Norton, 1992; Kaplan \& Norton, 1996a; Kaplan \& Norton, 1996b; Kaplan \& Norton, 2000) with analytical network process to measure the relative performance of an educational unit in Iran. Fazli and Jafari (2002) applied a hybrid MCDM model, which presents the dependent relationships among criteria with DEMATEL method (Shen et al., 2011) to construct a relations-structure among criteria. They used ANP to determine the relative weights of each criterion with dependence and feedback, and the VIKOR (Opricovic, 1998; Opricovic \& Tzeng, 2007) method was used to rank and select the best alternatives for investment.

\section{The proposed study}

\subsection{Analytical network process (ANP)}

Many multi criteria decision making (MCDM) techniques do not handle the interdependences among elements and to cope such problem, analytical network process (ANP) as an MCDM method was introduced by Saaty (1996). He demonstrated various types of ANP techniques, such as the Hamburger Model, the Car Purchase BCR model, and the National Missile Defense model (Saaty, 2004). The proposed model of this paper recommends a modified Feedback System model shown in Fig. 1, which takes into account inner dependences within the criteria.

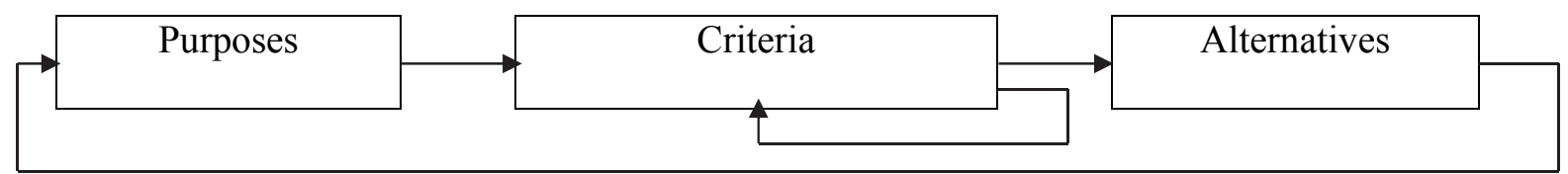

Fig.1. Feedback system model

To measure the relative importance among elements, 30 decision makers in this survey are requested to reply through a series of pair-wise comparisons based on the Saaty's nine-point scale 1-9. For evaluating the weights of elements, while analytical hierarchy process (AHP) (Saaty, 1988, 1990) uses the principal eigenvector of comparison matrix, the ANP implements the limiting process of the supermatrix (Sekitani \& Takahashi, 2001). The case study of this paper is associated with an Iranian firm whose primary concern is to manufacture three groups of products, namely auto-part, railway-part and others. These products are compared in terms of four major criteria; namely cost, sales figures, supply of raw materials and quality. Fig. 2 shows the structure of the proposed study.

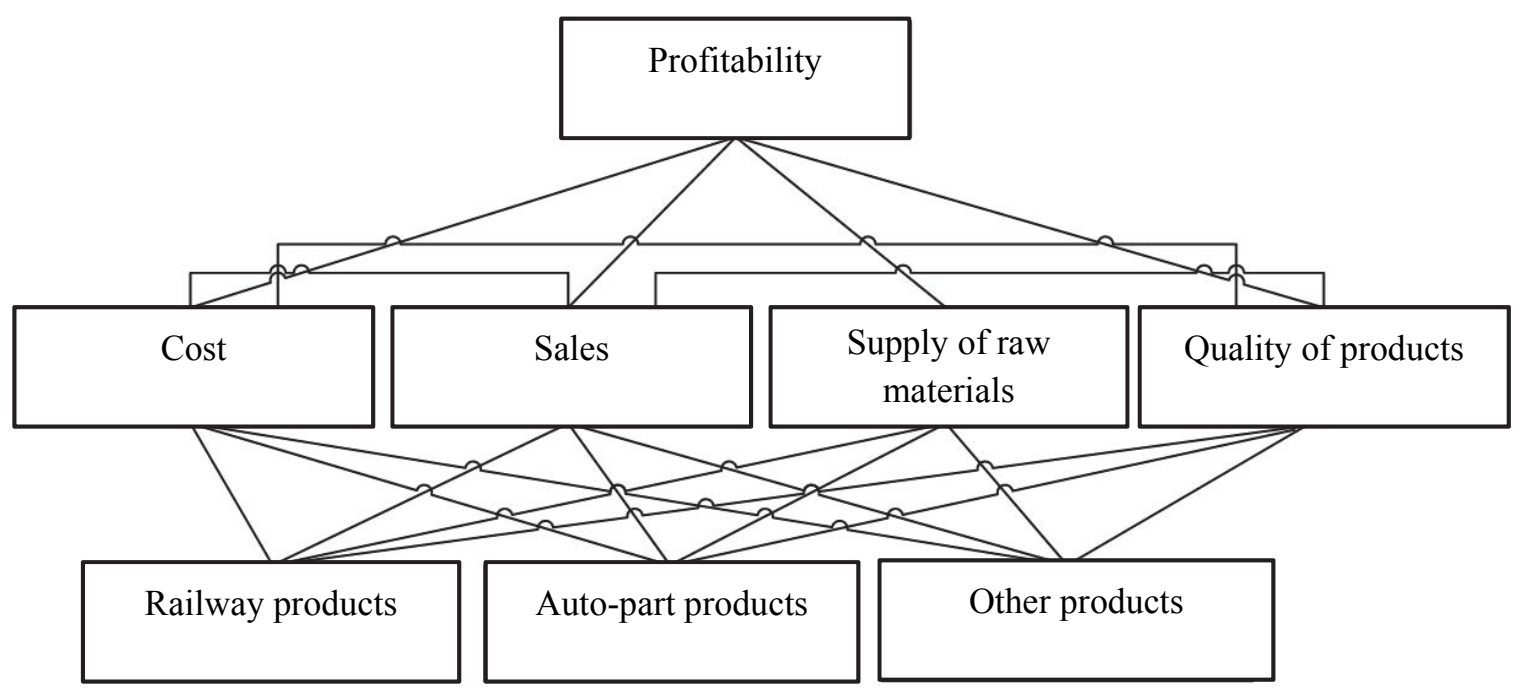

Fig. 2. The structure of the proposed study 
To perform pairwise comparison, the study uses the insights of 30 managers who were working for the firm in different positions. Fig. 3 shows personal characteristics of the participants.

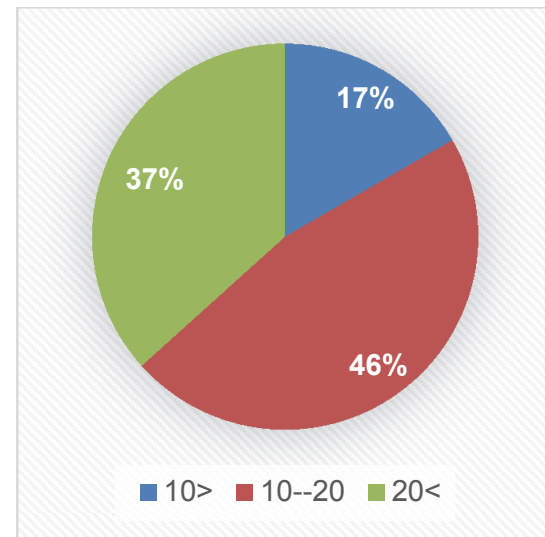

Years of job experiences

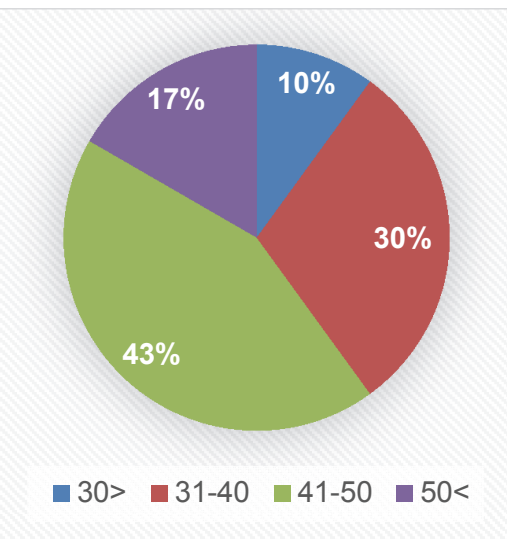

Age

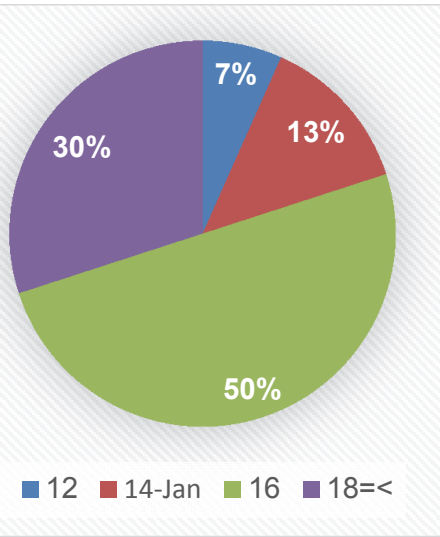

Years of educations

Fig. 3. Personal characteristics of the participants

According to the results of Fig.3, 83\% of the people who took part in this survey maintained at least 10 years of job experiences. In terms of their age, $10 \%$ of them aged less than 30 and the rest of them were mainly middle aged people and finally, most participants in our study hold good educational background. Table 1 shows the super matrix used for the proposed study.

\section{Table 1}

The results of super matrix used for the proposed study

\begin{tabular}{ccccccccc}
\hline & Objective & Cost & Sales & Raw materials & Quality & Railway & Auto-part & Others \\
\hline Objective & - & - & - & - & - & - & - & - \\
\hline $\begin{array}{c}\text { Cost } \\
\text { Sales }\end{array}$ & & & & & & & & \\
$\begin{array}{c}\text { Raw materials } \\
\text { Quality }\end{array}$ & A & & & B & & & C & \\
\hline $\begin{array}{c}\text { Railway products } \\
\text { Auto-part products } \\
\text { Other products }\end{array}$ & - & - & & & D & & - & - \\
\hline
\end{tabular}

\section{The results}

In this section, we present the results of the pairwise comparisons for different criteria and alternatives. Table 2 shows the results of the comparisons for different criteria.

\section{Table 1}

The results of pairwise comparison in section A

\begin{tabular}{lcccc}
\hline Criteria & Cost & Sales & Raw materials & Quality \\
\hline Weight & 0.409479 & 0.26369 & 0.213553 & 0.113278 \\
\hline
\end{tabular}

As we can observe from the results of Table 1, cost of production is the most important criterion followed by sales figures, supply of raw material and quality. Table 2-4 present the results of pairwise comparison in section $\mathrm{B}, \mathrm{C}$ and $\mathrm{D}$. 
Table 2

The results of pairwise comparison in section B

\begin{tabular}{lcccc}
\hline Criteria & Cost & Sales & Raw materials & Quality \\
\hline Cost & 0.564 & 0.093 & 0.291 & 0.118 \\
Sales & 0 & 0.422 & 0.085 & 0.263 \\
Supply of raw materials & 0.055 & 0.047 & 0.402 & 0.504 \\
Quality & 0 & 0 & 0 & 0 \\
\hline
\end{tabular}

Table 3

The results of pairwise comparison in section $\mathrm{C}$

\begin{tabular}{lccc}
\hline Criteria & Railway products & Auto-part products & Other products \\
\hline Cost & 0.144 & 0.150 & 0.145 \\
Sales & 0.136 & 0.150 & 0.125 \\
Supply of raw materials & 0.136 & 0.112 & 0.188 \\
Quality & 0.136 & 0.168 & 0.089 \\
\hline
\end{tabular}

\section{Table 4}

The results of pairwise comparison in section $\mathrm{D}$

\begin{tabular}{lcccc}
\hline Criteria & Cost & Sales & Raw materials & Quality \\
\hline Railway products & 0.368 & 0.304 & 0.333 & 0.403 \\
Auto-part products & 0.368 & 0.391 & 0.238 & 0.376 \\
Other products & 0.263 & 0.323 & 0.429 & 0.198 \\
\hline
\end{tabular}

Finally, Table 5 presents the results of super-matrix.

\section{Table 5}

The summary of the results of super matrix

\begin{tabular}{ccccccccc}
\hline & Objective & Cost & Sales & Quality & Supply & Railway & Auto & Others \\
\hline Objective & - & - & - & - & - & - & - & - \\
Cost & 0.40947 & 0.564 & 0.093 & 0.291 & 0 & 0.144 & 0.150 & 0.145 \\
Sales & 0.26369 & 0 & 0.422 & 0.085 & 0.118 & 0.136 & 0.150 & 0.125 \\
Quality & 0.21355 & 0.055 & 0.047 & 0.402 & 0.263 & 0.136 & 0.112 & 0.188 \\
$\begin{array}{c}\text { Supply of raw } \\
\text { materials }\end{array}$ & 0.11327 & 0 & 0 & 0 & 0.564 & 0.136 & 0.168 & 0.089 \\
\hline Railway-part & - & 0.368 & 0.304 & 0.333 & 0.403 & - & - & - \\
Auto-part & - & 0.368 & 0.391 & 0.238 & 0.376 & - & - & - \\
Others & - & 0.263 & 0.323 & 0.429 & 0.198 & - & - & - \\
\hline
\end{tabular}

Based on the results of the survey given in Table 5, we are now able to present the results of ranking in Table 6 as follows,

Table 6

The results of ranking of different products

\begin{tabular}{lccc}
\hline Products & Railway-part & Auto-part & Others \\
\hline Weight & 0.0984 & 0.1181 & 0.0689 \\
\hline
\end{tabular}




\section{Conclusion}

In this paper, we have presented an empirical investigation to prioritize different groups of products according to various criteria. The proposed study has implemented analytical network process to consider the interrelationships among various criteria. The results have indicated that it is possible to reach better profitability by concentrating on auto-part production. The results are consistent with recent development of auto-industry in Iran since this sector was under an embargo until recent years and the recent political change in Iran may create better opportunities for auto part makers to expand their operations.

\section{Acknowledgement}

The authors would like to thank the anonymous referees for constructive comments on earlier version of this paper.

\section{References}

Abedini, E., Naami, A \& Modiri, M. (2013). A study on ranking ethical factors influencing customer loyalty. Management Science Letters, 3(10), 2597-2602.

Atafar, A., Shahrabi, M \& Esfahani, M. (2013). Evaluation of university performance using BSC and ANP. Decision Science Letters, 2(4), 305-311.

Fazli, S., \& Jafari, H. (2002). Developing a hybrid multi-criteria model for investment in stock exchange. Management Science Letters, 2(2), 457-468.

Kuan, M \& Chen, Y. (2014). A hybrid MCDM framework combined with DEMATEL-based ANP to evaluate enterprise technological innovation capabilities assessment. Decision Science Letters, 3(4), 491-502.

Kaplan, R. S., \& Norton, D. (1992). The balanced scorecard measures that drive performance. Harvard Business Review, 70(1), 71-79.

Kaplan, R.S., \& Norton, D. (1996a). Using the balanced scorecard as a strategic management system. Harvard Business Review, 74(1), 75-85.

Kaplan, R.S., \& Norton, D.P. (1996b). The Balanced Scorecard: Translating Strategy into Action. Harvard Business School Press.

Kaplan, R.S., \& Norton, D.P. (2000). The strategy-focused organization: How balanced scorecard companies thrive in the new business environment. Harvard Business Press.

Opricovic, S. (1998). Multicriteria optimization of civil engineering systems. Belgrade: Faculty of Civil Engineering.

Opricovic, S., \& Tzeng, G. H. (2007). Extended VIKOR method in comparison with outranking methods. European Journal of Operational Research, 178(2), 514-529.

Paul, D., Agarwal, P., Mondal, G \& Banerjee, D. (2015). A comparative analysis of different hybrid MCDM techniques considering a case of selection of 3D printers. Management Science Letters, 5(7), 695-708.

Saaty, T. L. (1988). What is the analytic hierarchy process?. In Mathematical models for decision support (pp. 109-121). Springer Berlin Heidelberg.

Saaty, T. L. (1990). How to make a decision: the analytic hierarchy process.European journal of operational research, 48(1), 9-26.

Saaty, T. L. (1996). The analytic network process-decision making with dependence and feedback. Pittsburgh, PA: RWS Publications.

Saaty, T. L. (2004). Decision making - the analytic hierarchy and network processes (AHP/ANP). Journal of systems science and systems engineering, 13(1), 1-35.

Sekitani, K., \& Takahashi, I. (2001). A unified model and analysis for AHP and ANP. Journal of the Operations Research Society of Japan, 44(1), 67-89. 
Shen, Y.-C., Lin, G. T. R., \& Tzeng, G.-H. (2011). Combined DEMATEL techniques with novel MCDM for the organic light emitting diode technology selection. Expert Systems with Applications, $38(3), 1468-1481$.

Zarepour, A \& Momeni, H. (2014). An application of ANP for ranking different factors influencing on demand for auto parts. Management Science Letters, 4(4), 631-634.

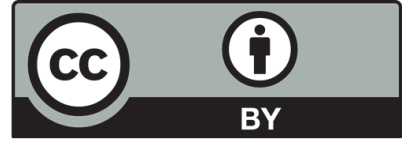

(C) 2016 by the authors; licensee Growing Science, Canada. This is an open access article distributed under the terms and conditions of the Creative Commons Attribution (CC-BY) license (http://creativecommons.org/licenses/by/4.0/). 